\title{
Transit oriented development - integrating land-use and transport in small island states
}

\author{
M. Borg \& R. Orsini \\ Projects Development and Coordination Unit (PDCU), \\ Ministry of Infrastructure, Transport and Communications, Malta
}

\begin{abstract}
European Cities are facing great challenges in the realm of urban development and mobility. The Lisbon Agenda has amplified Europe's vision and spearheaded directives towards sustainable cities and development. The Leipzig Charter (2007) is currently consolidating the focus on the implementation of urban development and planning based on integrated approaches to create sustainable cities and communities. Malta as an Island State faces bold decisions and changes in the realm of strategic and integrated planning in the long term. Responding to new EU Directives is an arduous task for a nation state with very particular characteristics with regards to governance and micro-economics.

After joining the European Union in 2004, Malta witnessed an increase in investments and strengthening of the economy. The country's population density of 1,269 per square kilometres is by far the highest in the EU and is one of the highest in the world. Moreover Malta has the most unsustainable fleet of private cars ranking 4th as part of the EU 27 for the highest number of cars per 1, 000 of the population. With a low percentage in modal split how can Transit Oriented Development respond to the exigencies of a small island state? How can this strategy be gauged through past experiences and available indicators?
\end{abstract}

Keywords: transit oriented development, integrated planning, smart growth, island states.

\section{Introduction}

'Green is cool' according to Architect Norman Foster and the way a city and its infrastructure is designed determines energy consumption patterns [1]. Although in 2006 'living and thinking green hit main street' the green agenda for more 
sustainable cities and transport has been a constant issue in European fora. But designing the future does not necessarily encompass designing new super cities with green transport measures. The devised Master Plan for Masdar in Abu Dhabi may be challenging with today's environmental concerns. A "zero carbon and waste free city" would be a world first, possibly a result of an utopist vision of a perfect city. The Masdar design brief that promises to question conventional urban wisdom at a fundamental level sets new benchmarks for the sustainable city of the future [1]. However, in the immediate present and in the European context, designing adaptable measures for the developing city tops the agenda. The Leipzig Charter on Sustainable European Cities, which evolves through a string of charters, conventions and directives [2], has sent a clear message from the European Ministers who; 'consider European cities of all sizes which have evolved in the course of history to be valuable and irreplaceable economic, social and cultural assets' [3].

But how can diverse city typologies apply European Union recommendations? In the Maltese Islands two years antecedent to the signing of the Leipzig Charter the newly developed Urban Development and Roads Ministry in Malta launched an integrated policy and vision towards urban development and transport. The mission of the government in 2005 was more of a national concern. It was to launch a holistic approach towards reaching one of the main government objectives and was set to trigger political debate over regeneration [4]. For this reason, a Cabinet Committee for the implementation of national projects was activated to address governance in urban development. With continuity in governance, urban development in the new 2008 legislature also falls under the newly established Ministry for Infrastructure, Transport and Communication. There are few examples in Europe that encompass holistic governance in this sector. The inclusion of Communication gives a further opportunity for the Maltese government to deliver 'Smart Growth' for the Harbour region and the Maltese Islands.

The Transit Oriented Development (TOD) Policy, which started as a research based consultation document, follows an integrated planning regime. The strategic plan initially started off as a process modelled document with research and benchmarking for formulation. In the past two years, the policy document went through an incremental process with a review system. It was directed through consultation and research phases in the light of European directives, new local legislative measures and evolution in governance. Malta as signatory to the Leipzig Charter was obliged to integrate, follow the set parameters and consolidate its position through an action programme. Transit Oriented Development Strategy proved to be a solid platform consonant with European Union declarations and recommendations even through not a conventionally applied planning tool in Europe.

\subsection{What is TOD? Is it green and is it sustainable?}

TOD proved to be an ideal tool as it gives various options when dealing with an array of different urban or developable areas or zones. For the purposes of this paper and the TOD strategy, the definition for TOD adopted and coined by the 
Department of Sustainability and Environment of the State of Victoria in Australia encapsulates the aspirations and objectives of the European Union and because it has a social base. It also refers to sustainable communities, sustainable urban development and transit modes in an integrated approach to achieve better results. TOD is a form of urban development "that clusters a greater mixture of land uses around a high quality transport service. The transport node, either train, light rail or bus terminus is designed to be the focus for the development and ideally becomes the community 'heart'. It is where people shop, work, meet, relax and live" [5].

In the benchmarking studies that have been compiled by the Projects Development and Coordination Unit (PDCU) common characteristics were identified. TOD nodes sustain compact communities through increased mobility and access. The compact community size supporting commercial and economic growth develops around transit zones with suitable walking distances. TOD policies address specifically the development of nodes and regeneration of areas for sustainable communities through; the grafting of new development and development of Transit Oriented Districts or Transit Villages [6].

The benefits from the implementation of TOD results in the development of accessible and permeable urban areas designed with the pedestrian in mind, increased public transit ridership and the reduction of car use and a pollution free or eco-friendly public realm. The best measured results with sustainability indicators come from the United States, Canada and Australia. These indicators may not be applied fully for Island States that have a micro-environment and regeneration projects based on micro-economies. Can agencies apply a 'one size fits all' in applying TOD indicators?

\section{Measuring TOD}

There have been numerous studies in an attempt to develop indicators to measure TOD performance. The holistic planning nature of TOD tends to make it complex not only to analyse and evaluate effects but also to effectively gather related data. From the documentation that has been collated by the PDCU on measuring TOD, it seems that Europe has still not grasped totally either the methodology or the processing for quantitative and qualitative data. This may come as a result of slow implementation and lack of structured adaptation of the system. In the United States of America and in Australia TOD has been developed not only as a discipline but also as a planning regime with solid governance. In either country case studies in measuring TOD have developed fine gauging mechanisms or barometers through 'best practice' and applications on the ground.

The American research digest of the National Cooperative Highway Research programme in 2005 presented key findings on "Transit-Oriented Development: Developing a Strategy to Measure Success" [7]. The study which involved 96 different agencies from various sectors refers to 56 different indicators which were categorized under five main groups; (i) travel behaviour (parking and traffic flow), (ii) economic (public and private investment), (iii) environmental 
(air quality and energy use), (iv) built environment (design quality, pedestrian friendliness, and land use) (v) social (diversity, safety, and affordability) [8].

In Australia the Department for Planning and Transport supports research projects connected with TOD. These projects contribute significantly to the Planning and Transport Research Centre (PATReC) programme, which examines key aspects of integrated transport and land use planning. In 2006, a research project was launched to set performance indicators in TOD [9]. This study was intended to measure the success of implementing developments in Western Australia. The measures studied included; (a) population density, (b) quality of streetscape design, (c) public transport patronage (d) rating of pedestrian safety, (e) housing density, (f) number of transit connections at stations, (g) pedestrian counts, (h) increase in property value, (i) number of mixed use buildings, (j) number of parking spaces. These measures may also be summed up under the five main categories that were listed in the American case study.

The categories for TOD indicators in both studies have been developed to measure the impacts in a holistic manner. In both cases the five general categories may be further sub-divided to fine tune the results. Similar indicators are also used in measuring; sustainability of projects, 'Smart Growth', City performance and Sustainable Urban Environment [10]. The promotion of 'best practice' in the realm of measuring performance contributed to the development of common tools to generate the best results in the area of sustainable integrated planning.

The crucial part in the process of creating indicators is the methodology or practice of collecting useful indicators in the easiest and most immediate way possible. The study conducted by John L. Renne and Jan S. Wells with American agencies shows how important environmental and sustainability indicators are in measuring TOD. The study quotes the rating of streetscape and pedestrian activity or equally important; the quality of the built environment. These however may not be the easiest indicators to collect. In fact, the study goes to show that statistical data as in the case of number of parking lots or ridership are very easy to collect and may be more precise. Indicators that may not be straightforward are still vital. The study concludes that specifically, pedestrian activity counts, public perception surveys, determination of economic outcomes, and quality of design call for more involved effort, expertise, and expense than may be available for the agencies [11]. The latter indicators may be the cardinal sectors that determine sustainability in the application of TOD in Island States especially those areas highly prone to gentrification, migration, social degeneration and desegregation of small communities.

\subsection{TOD in Europe and applied to the Maltese Islands}

Although TOD in Europe may not be a popular term other forms or hybrids have been identified which seek integrated urban and transport planning to achieve sustainable regeneration [12]. The positive results on the implementation of TOD 
in Europe have also been significant. The PDCU developed a benchmarking study by considered five European Cities or agglomerations including the City of Valletta as an example of medium sized Island City State and Naples with a metropolis of a million inhabitants.

The study called for the gauging of the effective performance of instruments deployed for the application of TOD strategies on the ground. The results although not quantifiable are encouraging. TOD has been effective for the regeneration of the historic fabric, for new estates or neighbourhoods developing around historic established quarters or for the redevelopment of brownfield sites or new residential zones.

Table 1: $\quad$ Effects of TOD driven projects in diverse cities in Europe [13].

\begin{tabular}{|l|c|c|c|c|}
\hline City/Area & Effects I & Effects II & Projects & Population \\
\hline \hline Valletta & + Access & + Mobility & Vertical Connection & $7 \mathrm{~K}-35 \mathrm{~K}$ \\
\hline & + Physical & -Congestion & Pedestrian & \\
\hline Echirolles & + Access & + Mobility & Rail/tram & $35-50 \mathrm{~K}$ \\
\hline \hline & + Physical & + Rehabilitation & New housing & \\
\hline Helsinki & + Access & + Mobility & Rail/tram & $50 \mathrm{~K}-200 \mathrm{~K}$ \\
\hline \hline Lyons & + +Access & +Mobility & Rail/tram & $200 \mathrm{~K}-500 \mathrm{~K}$ \\
\hline \hline & + Housing & + Mixed & Residential Quarters & \\
\hline Naples & + Access & +Mobility & Metroline & $1 \mathrm{M}$ \\
\hline & + Stations & + Housing & 5 Nodes & \\
\hline
\end{tabular}

The first TOD designed project for Valletta, the smallest of cities was the Vertical Connection. The Brief was developed in 2005 and the project is currently being negotiated with the winning consortium. The effects of the Vertical Connection which seeks to develop a Gateway to the Capital City and regenerate a dilapidated part of the fortifications is based on a park and ride with vertical connections. The integration with the bus loop and ferry is the effective strategic implementation of TOD and Travel Demand Management. The scope of the Vertical Connection is to instigate further modal shift and modal split and to lessen traffic congestion in the city environs. This had been transmitted successfully in the Park and Ride at Floriana with full capacity in car-parking at 
the peak hours and high ridership throughout its first months of implementation. The popular use of electric mini cabs in the capital City together with the pedestrianisation of Valletta increased modal-split and reduced pollution levels.

\section{TOD and smart growth for the Maltese Islands}

With these projects in the pipeline the PDCU set a task to promote regular performance benchmarking to test TOD applications in the Maltese Islands. The indicators being compiled are set to respond to definite criteria namely; TOD, sustainability, Leipzig Charter parameters, design and energy efficiency. Although these parameters may be set on other guidelines in non-member states or diverse cities the tools have to be fine tuned to the particular characteristics of the Maltese Islands. These characteristics may be replicated in other small island states or small states in Europe and non-member states. One main indicator of unsustainable development is private car ownership and low modal split percentage. This is a common trend in most small states in global terms and reflects a crucial dichotomy. Small states should be more energy efficient with mass transit as a more sustainable alternative with shorter distances to travel. The study concluded that a majority of these areas concentrate transport infrastructure networks around the capital causing hindrance to urban mobility, stimulating unnecessary journeys to the capital. Table 2 offers comparative benchmarks in the density and private car use. It shows how small nations, island regions and states appear to have the highest car ownership in the world, despite their relative small sizes. The lack of real investment in the public transport networks and cultural trends has fuelled private car use and unsustainable environmental results. The statistics do not reflect 'Smart Growth' and with respect to Malta as part of the new EU ten the period to effectively implement European charters is not extensive. Malta has 2020 as the year set for the reduction of Green House emissions.

The Inner Harbour region in the Maltese Islands is a major conurbation including 13 councils and a population of 70,000 in an area of 500,000 square metres. The situation of access and mobility has created gentrification and a community within the harbour area that is predominantly aged $(60+)$. This population is characterised by high unemployment rates. When compared to the local average of (7.8\%) two of the localities feature high in the list with Bormla $5.4 \%$ (second) and Valletta 4.9\% (third). The generous social welfare state has been sustained through the Post-Independence years with abundant housing provision and unemployment benefits. This unfortunately has not kept poverty at bay and 2002 statistics quote Malta with $15 \%$ with the risk of poverty which is comparatively high when gauged with the then EU 15 average (18\%).

The Maltese situation is not all 'doom and gloom'. A forecast over the next five year period shows an increment in regeneration project development with an estimated value of the capital investment set to increase from $€ 385$ to $€ 506$ Million. The percentage of modal split has also been raised by $10 \%$ in a five years span. New transport modes have been adopted fully with an encouraging response of the public participation of up to $85 \%$ willing to pay for the service. 
Table 2: $\quad$ Comparative indicators for population density and private cars. Data sources: EU - DG for Energy and Transport, 'EU Energy and Transport in figures' and the World Bank, 'World Development Indicators'.

\begin{tabular}{|c|c|c|c|}
\hline Country & Population & $\begin{array}{c}\text { Population Density } \\
\text { (Persons per sq km) }\end{array}$ & $\begin{array}{c}\text { Passenger Cars Per } \\
1,000 \text { population }\end{array}$ \\
\hline EU (All 27) & $\mathbf{4 9 3} \mathbf{~ m}$ & $\mathbf{4 , 6 4 6}$ & $\mathbf{4 6 6}(\mathbf{2 0 0 6})$ \\
\hline Austria & $8 \mathrm{~m}$ & 100 & $507(2006)$ \\
\hline Belgium & $11 \mathrm{~m}$ & 349 & $470(2006)$ \\
\hline Cyprus & $779 \mathrm{k}$ & 83 & $479(2006)$ \\
\hline Estonia & $1 \mathrm{~m}$ & 32 & $413(2006)$ \\
\hline Finland & $5 \mathrm{~m}$ & 17 & $475(2006)$ \\
\hline France & $62 \mathrm{~m}$ & 111 & $504(2006)$ \\
\hline Germany & $82 \mathrm{~m}$ & 236 & $566(2006)$ \\
\hline Greece & $11 \mathrm{~m}$ & 86 & $407(2006)$ \\
\hline Hungary & $10 \mathrm{~m}$ & 112 & $293(2006)$ \\
\hline Ireland & $4 \mathrm{~m}$ & 62 & $418(2006)$ \\
\hline Italy & $59 \mathrm{~m}$ & 200 & $597(2006)$ \\
\hline Latvia & $2 \mathrm{~m}$ & 37 & $360(2006)$ \\
\hline Luxembourg & $476 \mathrm{k}$ & 178 & $661(2006)$ \\
\hline Malta & $\mathbf{4 0 8 ~ k}$ & $\mathbf{1 , 2 6 9}$ & $\mathbf{5 3 5 ( 2 0 0 6 )}$ \\
\hline Netherlands & $16 \mathrm{~m}$ & 482 & $442(2006)$ \\
\hline Poland & $38 \mathrm{~m}$ & 124 & $351(2006)$ \\
\hline Portugal & $11 \mathrm{~m}$ & 116 & $405(2006)$ \\
\hline Romania & $22 \mathrm{~m}$ & 94 & $167(2006)$ \\
\hline Slovenia & $2 \mathrm{~m}$ & 100 & $488(2006)$ \\
\hline UK & $61 \mathrm{~m}$ & 250 & $471(2006)$ \\
\hline Liechtenstein & $35 \mathrm{k}$ & 218 & $688(2006)$ \\
\hline Norway & $5 \mathrm{~m}$ & 15 & $439(2005)$ \\
\hline San Marino & $29 \mathrm{k}$ & 477 & $1,068(2006)$ \\
\hline Switzerland & $7 \mathrm{~m}$ & 187 & $520(2005)$ \\
\hline Isle of Man & $81 \mathrm{k}$ & 146 & $625(2003)$ \\
\hline Guernsey & $64 \mathrm{k}$ & 816 & $630(2002)$ \\
\hline Jersey & $90 \mathrm{k}$ & 757 & $826(2002)$ \\
\hline Australia & $21 \mathrm{~m}$ & 3 & $542(2005)$ \\
\hline Canada & $33 \mathrm{~m}$ & 4 & $551(2005)$ \\
\hline Japan & $128 \mathrm{~m}$ & 350 & $441(2005)$ \\
\hline New Zealand & $4 \mathrm{~m}$ & 16 & $607(2005)$ \\
\hline USA & $299 \mathrm{~m}$ & 33 & $290(2005)$ \\
\hline Bahamas & $327 \mathrm{k}$ & 33 & $343(2005)$ \\
\hline Barbados & $293 \mathrm{k}$ & 681 & $133(2005)$ \\
\hline Jamaica & $3 \mathrm{~m}$ & 246 & \\
\hline & & & \\
\hline
\end{tabular}


Smart growth is being further fuelled by a 'showcase' project Smart City in the inner harbour, which will convert an industrial estate into a mixed use regeneration node, based on Information and Communication Technology (ICT). The investment of $€ 192 \mathrm{M}$ will spur further 'Smartisland' policy [14].

\subsection{Measuring the effects of TOD}

In the past two years PDCU launched another three TOD projects namely; 'Dock No.1', 'Marsascala Transit Village' and the 'Cottonera Action Plan - Social Inclusion through better mobility and accessibility'. The main objectives of these projects is to deliver TOD through the principle of sustainable communities to make sure that neighbourhoods are equipped to respond to challenging economic, social and cultural developments. The projects and action plans promote social inclusion and subsidiarity through partnerships, which are the vehicle to create better accessibility within the social texture of the areas. The points of reference in the urban fabric are enhanced through 'good design'.

Table 3: $\quad$ Table shows a selection of TOD indicators for the Maltese Islands.

\begin{tabular}{|c|c|}
\hline Main Categories & Specific Indicators \\
\hline \multirow[t]{3}{*}{ Travel behaviour } & modal Split \\
\hline & parking \\
\hline & traffic flow \\
\hline \multirow[t]{4}{*}{ Economic } & private investment in regeneration \\
\hline & public investment in regeneration \\
\hline & cultural tourism percentage increase \\
\hline & small business development \\
\hline \multirow[t]{3}{*}{ Environmental } & air quality \\
\hline & use of solar energy (PVP) \\
\hline & use of alternative transport modes \\
\hline \multirow[t]{5}{*}{ Built environment } & pedestrian friendly accessibility \\
\hline & heritage assets (adaptive reuse) \\
\hline & design quality \\
\hline & landscape architecture interventions \\
\hline & landuse and mixed use ratio \\
\hline \multirow[t]{4}{*}{ Social } & affordability \\
\hline & migration \\
\hline & social inclusion initiatives \\
\hline & cultural heritage initiatives \\
\hline
\end{tabular}

To adhere to the Leipzig Charter principles of 'Baukultur' the action plans promote design that has a direct impact on the quality of life of every citizen. The action plans and projects also seek to promote energy efficiency as a means to fully adhere to European policies tackling climate change and follow the Green Paper on Urban Transport. Energy efficiency is a crucial component in regeneration and planning to encourage the growth of an eco-friendly society. Although the indicator categorisation in the Maltese case still pursues the TOD 
established indicators the variants will target less conventional indicators; the performance of small and medium enterprises or the development and activities by NGOs and cultural heritage groups. These may not indicate the dynamism and vibrancy of societies outside Maltese waters but are indicators of healthy community life in Maltese towns and cities. In the same way, the rehabilitation and adaptive re-use of abandoned historic military or naval complexes, the promotion of cultural tourism and population migration into old cores may not be cardinal indicators for many cities. In the Maltese case however these are crucial indicators of sustainable growth and the effectiveness of TOD objectives.

\section{Conclusions}

The implementation of TOD and gauging its success on micro-environments with micro-economies reflects the flexible nature of this planning tool. The effect of TOD on small communities and neighbourhoods measures its possibilities applied strategically at all levels of city fabric and texture. The Maltese case study points towards the possible adaptation of TOD in diverse cities and its encouraging results vis-à-vis sustainability, 'smart growth' and the promotion of green cities.

European cities of all sizes may still be examples of 'cool green' initiatives without resorting to radical Master Plans. The adaptability to new planning regimes stemming from sustainability and environmentally driven policies may ultimately contribute to the implementation of EU cohesion directives and recommendations. TOD has ultimately given a new lease of life for cities. It presents a possibility for cities to evolve without compromising these valuable and irreplaceable economic, social and cultural assets. Measuring the sustainability of these initiatives will always be more important than the implementation. It is through research networks that results may be calibrated on a European and world-wide level. Comparative benchmarking may assist in further developing tools for sustainable planning through experience and applications on the ground. The results from research programmes and fora funded by the European Union as in the case of URBACT, INTERREG and the European Urban Knowledge Network (EUKN) have catalysed the possibilities of research on an inter-regional and inter-state framework offering a spectrum of applications in diverse cities. It was wise that the Ministers' declaration as part of the Leipzig Charter considered the development of a wide knowledge base between European cities through cooperation. This incentive will give smaller cities and states the possibility of applying research on the ground and ultimately test planning systems and methods to achieve sustainable development through diversity.

\section{References}

[1] Lunch over IP website: DLD07: Norman Foster's "green is cool", Running notes from the Digital Life Design DLD07 conference in Munich, 2007. http://www.lunchoverip.com/2007/01/dld07_norman_fo.html 
[2] French EU Presidency, Lille Action Programme, November 2000. Commission, Gothenburg Strategy website, June 2001: http://ec.europa.eu/sustainable/welcome/index_en.htm. Dutch EU Presidency, Rotterdam Urban Acquis', January 2005. UK EU Presidency, the Bristol Accord, December 2005. German EU Presidency, Leipzig Charter, May 2007. Directorate-General for Energy and Transport, European Commission, Green Paper on urban mobility, September 2007. Growth for Jobs, European Commission, Lisbon Strategy official website: http://ec.europa.eu/growthandjobs/index_en.htm. European Commission, DG for the Environment website: http://ec.europa.eu/environment/eussd/.

[3] German EU Presidency, Leipzig Charter, 24th/ 25th May 2007.

[4] Government of Malta, Operational Programme I (OPI), 'Investing in Competitiveness for a Better Quality of Life'.

[5] Department of Sustainability and Environment, State Government of Victoria, Australia, Melbourne 2030, official website: www.dse.vic.gov.au/melbourne2030online.

[6] C-I-T-UM Thematic Network, URBACT 1, C-I-T-UM Guide to Urban Mobility, July 2007.

[7] Renne, J \& Wells, J, Voorhees Transportation Center, Edward J. Bloustein School of Planning and Public Policy, Rutgers University, Research Results Digest 294, National Cooperative Highway Research Program, Transportation Research Board, USA, Transit-Oriented Development: Developing a Strategy to Measure Success, February 2005.

[8] Renne, J \& Wells, J, Voorhees Transportation Center, - Op.cit. pp. 3-19.

[9] Department for Planning and Infrastructure, State Government of Western Australia, Australia, official website: http://www.dpi.wa.gov.au/ cityregionalplanning/15683.asp

[10] Hoornweg, D (World Bank), Ruiz, N (World Bank), Ruiz Nuñez, F (World Bank), Freire, M (World Bank), Palugyai, N (World Bank), Villaveces, M (University of Ontario Institute of Technology) \& Herrera, W (Universidad de los Andes), World Bank, World Bank Policy Research Working Paper 4114, City Indicators: Now to Nanjing, January 2007.

[11] Renne, J \& Wells, J, Voorhees Transportation Center, - Op.cit. p 22

[12] In the UK a similar integrated planning tool Transport Development Areas (TDA) is being advocated by the Royal Institute of Chartered Surveyors (RCIS).

[13] (Former) Ministry for Urban Development and Roads, Malta, A Public Strategy for Malta. 2005. \& evaluating the findings of Papa, E. \& Giovanna Trifiletti, E, Department of Spatial Planning DiPiST University of Naples, Naples, Italy.

[14] (Former) Ministry for Investment, Industry \& Information Technology, Malta, Website: http://www.miti.gov.mt/site/page.aspx?pageid=1700 